\title{
What are Driving Factors of Entrepreneurial Intention? Perspectives from Start-Up Founder in Jakarta-Indonesia
}

\author{
Sevenpri Candra ${ }^{1}$, Geryan Junanta ${ }^{2}$, Jauharil Achsan Hardani ${ }^{3}$ \\ \{seven@binus.ac.id ${ }^{1}$; geryanjunanta@binus.ac.id ${ }^{2}$; jauharil.hardani@binus.ac.id ${ }^{3}$ \} \\ Management Department, BINUS Business School Undergraduate Program, Bina Nusantara \\ University, Jakarta, Indonesia $11480^{123}$
}

\begin{abstract}
The growth of start-ups has risen significantly in Indonesia. There is a positive impact on that risen; several start-ups became unicorns and above. However, this growth is not following by continued improvement in entrepreneurial knowledge. Moreover, there are minimal studies that examined what is happening in Indonesia. This study will contribute to Indonesia's entrepreneurial growth, especially given to know the driving factors of Indonesia's entrepreneurial intentions from Indonesia are? This research will be using snowball sampling and analysis by Sequential Equation Modeling with WarpPLS Software. A questionnaire will be distributed through the social media platform. 217 respondents collect through this study, and the majority are millennial's. Entrepreneurial Intentions are driving by entrepreneurial passion and creativity, but entrepreneurial selfefficacy is less in this study.
\end{abstract}

Keywords: Creativity, Entrepreneurial Passion, Entrepreneurial Self-Efficacy, Entrepreneurial Intention

\section{Introduction}

The development of start-ups in Indonesia is increasing. This has happened since the success of several start-ups that became unicorns and above; call it Go-Jek, Tokopedia, and Traveloka [1,2]. Furthermore, in the growth of start-ups globally, Indonesia is in the fourth position, and at the ASEAN level, it is in the first position [2]. Most start-ups in Indonesia were born and developed in DKI Jakarta. Seeing the development of this ever-increasing start-up growth makes it interesting to study further, especially related to entrepreneurial intention among start-ups in DKI Jakarta. There have been many similar studies, but there are still minimal studies that portray Indonesia's things.

Entrepreneurial intention can be defined as an initial concept and idea carried out to start a business. Entrepreneurial intention is a specific target for determining behavior in starting a business [3-5]. Where passion is a positive feeling that is felt when establishing a new business, the intention is more to the real action to establish a company $[4,6,7]$. In this research, creativity is added, like developing ideas owned by start-up founders in running their business $[3,8,9]$. Besides passion and creativity, there are additional variables to determine whether passion and creativity have a relationship with entrepreneurial intention with entrepreneurial self-efficacy as a mediator [10-12]. This study uses Social Cognitive Theory (SCT) to find out how start-up founders have the intention to establish a start-up business, whether having passion and creativity is enough to grow the intention to establish a start-up [13]. SCT itself argues that learning occurs from dynamic reciprocal interactions between people, environment, and 
behavior. This study's results can help organizations understand what factors are needed when establishing a start-up, especially start-ups in Indonesia.

\section{Literature Review}

Entrepreneur Intention refers to specific behaviors in starting a business. Intention helps start-up founders predict actions to be taken and reflect a commitment to founding a start-up business $[3,4,12]$. In contrast to entrepreneurial passion, which acts as a positive feeling in founding a business, entrepreneurial intention is more about establishing the business. Individuals who have a high passion might cause an intention to start a business, and it depends on several factors that can facilitate or hinder. Ref. [3,5] explores a theory of how entrepreneurial passion can develop and influence the intention to become an entrepreneur for individuals who are not yet an entrepreneur. For this reason, this research will evaluate the extent to which individuals who have high passion can have the intention to establish a business.

Passion is a particular emotion that is commonly felt by entrepreneurs [7,14-16]. Individuals who experience entrepreneurial passion have strong positive feelings in carrying out entrepreneurial activities and have a solid motivation to follow these feelings $[3,7,16]$. Constructive measurements have been developed based on three dimensions of entrepreneurial identity types: inventing, founding, and developing a business [3,7]. Passion is one part of the personal factors in the SCT and sometimes able to help overcome specific obstacles when forming a new business $[10,13,16]$. The passion for creating value and making an impact is significant for an entrepreneur's nature [17]. Someone who has a passion for founding a new company will positively influence carrying out activities related to finding a new market location, increasing capital, etc. [3,18]. In the context of a start-up business, individuals involved in start-up business are those who have their motivation.

Creativity refers to developing ideas that are new and useful, both in the short and long term $[8,19]$. Creativity can also arise from interactions between individuals and the environment [20]. The founders will experience problems when establishing their start-up business, such as limited financial resources, limited technology, and limited human resources. Someone (who in this case is a start-up founder) who can get through this challenge has a high level of creativity, and that can be achieved when interacting with other founders to share tips and ways to overcome the problem of existing limitations [21,22]. Besides, creativity can also arise by studying the founders who have successfully run their start-up business; that way is called vicarious learning that has been explained in SCT theory [13]. Creativity is essential for start-up founders because it can help founders overcome every obstacle they will face when establishing a start-up business. Research on career anchors has linked creativity with motivation to establish one's own business, arguing that individuals who have high creativity tend to be interested in career choices to become entrepreneurs $[9,23,24]$.

A high level of entrepreneurial passion and the capacity to find new solutions creatively is vital for creating entrepreneurial intention. An individual can feel obstacles as challenges even they are determined to overcome these problems $[11,12,24]$. Therefore, when starting a business, individuals must be confident in their abilities to succeed and achieve their goals. Belief in one's abilities is what is referred to as self-efficacy. Self-efficacy itself is the center of the SCT, which plays a role in improving the ability to complete existing tasks and achieve the goals [13]. Entrepreneurial self-efficacy is an essential requirement for start-up founders to establish a business because self-efficacy is related to completing tasks and achieving goals $[5,12]$. Passion has been found to grow one's confidence $\&$ competence and associated with a higher level of entrepreneurial self-efficacy $[7,15]$. It can be concluded that entrepreneurial selfefficacy can be considered a factor that mediates entrepreneurial passion with entrepreneurial 
intention. Ref. [23] described creating new ideas, products, and so on leads people to examine their capacity to become entrepreneurs. Thus, if someone already has creativity, then they can overcome existing obstacles.

\section{Research Method}

The design of this study will use a descriptive associative approach with the unit of analysis is the individual. The sampling technique used is snowball sampling, with the target respondents being the start-up founder in DKI Jakarta [25]. Questionnaires will be distributed online through social media platforms such as Line, WhatsApp, and Instagram. The Structural Equation Modeling analysis method will be used with WarpPLS software [26,27].

\section{Research Finding and Discussions}

From distributing questionnaires conducted through social media platforms, 217 respondents were willing to fill in completely. The complete analysis of the respondents' profiles can be seen in Table 1. While the hypotheses will be analyzed using the WarpPLS Software [27]. There are two measurement processes: the Measurement Model and the Structural Model $[28,29]$. The Measurement Model will see the validity and reliability for each construct used, as shown in Table 2. The Structural Model will be seen in the measurement of the Model Fit Indicator in Table 3. From the whole process, it can be concluded that all processes have fulfilled the basic requirements.

For this reason, a hypothesis analysis is performed by looking at p-values and path coefficients. And the results of this study conclude that Entrepreneurial Self-Efficacy does not provide a moderating relationship both for Creativity and Entrepreneurial Passion. Whereas Entrepreneurial Intentions can be formed from Entrepreneurial Passion and Creativity. The complete test results of this hypothesis can be seen in Figure 1.

Table 1. Demographic Characteristics

\begin{tabular}{lrrr}
\hline Profile Respondents & Frequency & Percentage \\
\hline \multirow{2}{*}{ Sex } & & 159 & \\
& Male & 58 & $26.73 \%$ \\
& Female & & \\
Ages & & 105 & $48.39 \%$ \\
& Below 25 & 110 & $50.69 \%$ \\
& $25-35$ & 2 & $0.92 \%$ \\
& $36-45$ & & \\
Status & & 186 & $85.71 \%$ \\
& Single & 31 & $14.29 \%$ \\
& Married & & \\
Longevity Start-up (months) & 61 & $28.11 \%$ \\
& Below 12 & 122 & $56.22 \%$ \\
& 13 - 35 & 30 & $13.82 \%$
\end{tabular}


Above $60 \quad 4 \quad 1.84 \%$

\begin{tabular}{llr} 
Type of Start-up & & \\
Services & 78 & $35.94 \%$ \\
Creative & 63 & $29.03 \%$ \\
Retail & 52 & $23.96 \%$ \\
Social Activity & 13 & $5.99 \%$ \\
Food \& Beverages & 11 & $5.07 \%$ \\
\hline
\end{tabular}

Table 2. Measurement Model Results

\begin{tabular}{|c|c|c|c|c|}
\hline \multirow[b]{2}{*}{ Constructs } & \multicolumn{2}{|c|}{ Validity Test } & \multicolumn{2}{|c|}{ Reliability Test } \\
\hline & $\begin{array}{l}\text { Loading } \\
\text { Factor }\end{array}$ & AVE & $\begin{array}{l}\text { Composite } \\
\text { Reliability }\end{array}$ & $\begin{array}{l}\text { Cronbach's } \\
\text { Alpha }\end{array}$ \\
\hline Creativity & & 0.899 & 0.909 & 0.873 \\
\hline I often solve problems with creative solutions & 0.841 & & & \\
\hline I often find new ideas & 0.839 & & & \\
\hline I often have new and innovative ideas & 0.863 & & & \\
\hline I can produce creative ideas & 0.856 & & & \\
\hline I often give ideas to other people & 0.669 & & & \\
\hline Entrepreneurial Passion & & 0.817 & 0.944 & 0.921 \\
\hline Having a company will make me excited & 0.874 & & & \\
\hline Establishing a new company is very interesting & 0.925 & & & \\
\hline Being a business founder is a significant part of my career & 0.915 & & & \\
\hline It is nice to be able to manage a new business & 0.881 & & & \\
\hline Entrepreneurial Self-Efficacy & & 0.814 & 0.935 & 0.896 \\
\hline How confident are you in making new products & 0.918 & & & \\
\hline How confident are you in identifying a new business opportunity & 0.91 & & & \\
\hline How confident are you in promoting a new idea & 0.902 & & & \\
\hline Entrepreneurial Intentions & & 0.887 & 0.917 & 0.863 \\
\hline $\begin{array}{l}\text { How much is your interest in turning your start-up business into } \\
\text { High-growth in the next } 5 \text { to } 10 \text { years }\end{array}$ & 0.922 & & & \\
\hline $\begin{array}{l}\text { How big is your intention in starting Business Startup in the next } \\
5 \text { to } 10 \text { years }\end{array}$ & 0.906 & & & \\
\hline How big is your intention to get Business Startup in 5 to 10 years & 0.83 & & & \\
\hline
\end{tabular}


Table 3. Structural Model Result

\begin{tabular}{lll}
\hline \multicolumn{1}{c}{ Criteria } & \multicolumn{1}{c}{ Results } & \multicolumn{1}{c}{ Rules } \\
\hline Average path coefficient (APC) & $0.251, \mathrm{P}<0.001$ & If $\mathrm{p}<0.05$, Good \\
Average R-squared (ARS) & $0.732, \mathrm{P}<0.001$ & If $\mathrm{p}<0.05$, Good \\
Average block VIF (AVIF) & 1.369 & If AVIF $<5$, Good \\
\hline
\end{tabular}

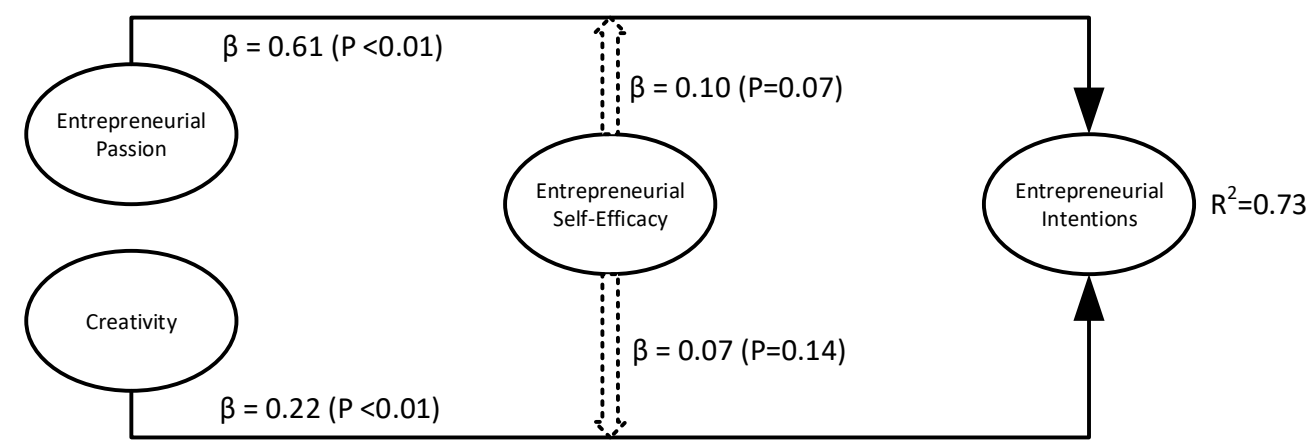

Fig. 1. Research Model Result

\section{Conclusions and Future Research}

The results showed a relationship between passion and entrepreneurial intention. This study proves that passion can trigger an intention to establish a business. Having the passion of startup founders will have a positive energy that can motivate them to start a business [3,14]. Passion can also help achieve success because having a passion will make the founders more passionate about solving problems, finding sources of capital, looking for resources needed, and all aspects needed to establish a business [7,18]. Creativity with entrepreneurial intention also has a relationship. Creativity is needed by start-up founders when establishing a business in order to be able to identify a market appropriately; this is the following that contained in research [20]. Creativity can also help solve any problem with the generation of ideas to find the right solution.

Entrepreneurial Self-Efficacy does not moderate the relationship between Entrepreneurial Passion and Entrepreneurial Intention. Start-up founders likely think that having passion is enough to set up a business. The notion of self-efficacy is the ability of individuals to believe in their abilities. For respondents, it is possible to develop abilities that will increase over time when they have established their business. Self-Efficacy cannot moderate the relationship between Creativity and Entrepreneurial Intention. Start-up founders may assume that creativity is enough to start a start-up. For respondents, the ability may increase and will make them more confident over time. From this study, it can be concluded that self-efficacy might be more appropriate for respondents who would develop an already established business. 
Entrepreneurial intention can arise if start-ups have a strong passion for dealing with all obstacles that arise in becoming entrepreneurs. Creativity also contributes to this entrepreneurial intention. By having creativity, the start-up founders will give their color to the business ideas or solutions offered. This study still has limitations in terms of respondents, and the factors studied are related to Entrepreneurial Intentions. For this reason, there is still room for research by using a more significant number of samples and by considering other variables that cannot be tested in this study. While the hypotheses do not support this research, they can be explored even more profoundly by looking at phenomena that occur from time to time.

\section{References}

[1] Budi O. Wow, Indonesia Masuk 5 Besar Negara Pencetak Startup Terbanyak di Dunia! MSN 2019. https://www.msn.com/id-id/ekonomi/bisnis/wow-indonesia-masuk-5-besar-negarapencetak-startup-terbanyak-di-dunia/ar-AAFotmg (accessed May 11, 2020).

[2] Rizal A. Menkominfo: Punya 2.193 Startup, Indonesia Kalahkan Negara Maju. Infokomputer 2020. https://infokomputer.grid.id/read/121999415/menkominfo-punya-2193-startup-indonesiakalahkan-negara-maju (accessed May 11, 2020).

[3] Biraglia A, Kadile V. The Role of Entrepreneurial Passion and Creativity in Developing Entrepreneurial Intentions: Insights from American Homebrewers. Journal of Small Business Management 2017;55:170-88. https://doi.org/10.1111/jsbm.12242.

[4] Krueger N. The Impact of Prior Entrepreneurial Exposure on Perceptions of New Venture Feasibility and Desirability*: Entrepreneurship Theory and Practice 2017. https://doi.org/10.1177/104225879301800101.

[5] Lee L, Wong PK, Foo MD, Leung A. Entrepreneurial intentions: The influence of organizational and individual factors. Journal of Business Venturing 2011;26:124-36. https://doi.org/10.1016/j.jbusvent.2009.04.003.

[6] Cardon MS, Foo M-D, Shepherd D, Wiklund J. Exploring the Heart: Entrepreneurial Emotion is a Hot Topic: Entrepreneurship Theory and Practice 2012.

[7] Cardon MS, Gregoire DA, Stevens CE, Patel PC. Measuring entrepreneurial passion: Conceptual foundations and scale validation. Journal of Business Venturing 2013;28:373-96. https://doi.org/10.1016/j.jbusvent.2012.03.003.

[8] Amabile TM. Creativity in context: Update to "The Social Psychology of Creativity." Boulder, CO, US: Westview Press; 1996.

[9] Zampetakis LA, Moustakis V. Linking creativity with entrepreneurial intentions: A structural approach. Entrepreneurship Mgt 2006;2:413-28. https://doi.org/10.1007/s11365-006-0006-z.

[10] Baum JR, Locke EA. The Relationship of Entrepreneurial Traits, Skill, and Motivation to Subsequent Venture Growth. Journal of Applied Psychology 2004;89:587-98. https://doi.org/10.1037/0021-9010.89.4.587.

[11] Rosique-Blasco M, Madrid-Guijarro A, García-Pérez-de-Lema D. The effects of personal abilities and self-efficacy on entrepreneurial intentions. Int Entrep Manag J 2018;14:1025-52. https://doi.org/10.1007/s11365-017-0469-0.

[12] Zhao H, Seibert SE, Hills GE. The mediating role of self-efficacy in the development of entrepreneurial intentions. J Appl Psychol 2005;90:1265-72. https://doi.org/10.1037/00219010.90.6.1265.

[13] Bandura A. Social foundations of thought and action: A social cognitive theory. Englewood Cliffs, NJ, US: Prentice-Hall, Inc; 1986.

[14] Cardon MS, Wincent J, Singh J, Drnovsek M. The nature and experience of entrepreneurial passion. AMR 2009;34:511-32. https://doi.org/10.5465/amr.2009.40633190.

[15] Murnieks CY, Mosakowski E, Cardon MS. Pathways of Passion: Identity Centrality, Passion, and Behavior Among Entrepreneurs. Journal of Management 2012. https://doi.org/10.1177/0149206311433855. 
[16] Newman A, Obschonka M, Moeller J, Chandan GG. Entrepreneurial Passion: A Review, Synthesis, and Agenda for Future Research. Applied Psychology 2019;n/a. https://doi.org/10.1111/apps.12236.

[17] Ma H, Tan J. Key components and implications of entrepreneurship: A 4-P framework. Journal of Business Venturing 2006;21:704-25. https://doi.org/10.1016/j.jbusvent.2005.04.009.

[18] Breugst N, Domurath A, Patzelt H, Klaukien A. Perceptions of Entrepreneurial Passion and Employees' Commitment to Entrepreneurial Ventures. Entrepreneurship Theory and Practice 2012;36:171-92. https://doi.org/10.1111/j.1540-6520.2011.00491.x.

[19] Zhou Q, Hirst G, Shipton H. Promoting Creativity at Work: The Role of Problem-Solving Demand. Applied Psychology 2012;61:56-80. https://doi.org/10.1111/j.1464-0597.2011.00455.x.

[20] Hansen DJ, Shrader R, Monllor J. Defragmenting Definitions of Entrepreneurial Opportunity*. Journal of Small Business Management 2011;49:283-304. https://doi.org/10.1111/j.1540627X.2011.00325.x.

[21] Ford CM. A Theory of Individual Creative Action in Multiple Social Domains. AMR 1996;21:1112-42. https://doi.org/10.5465/amr.1996.9704071865.

[22] Hunter ST, Bedell KE, Mumford MD. Climate for Creativity: A Quantitative Review. Creativity Research Journal 2007;19:69-90. https://doi.org/10.1080/10400410709336883.

[23] Baron RA. The Role of Affect in the Entrepreneurial Process. AMR 2008;33:328-40. https://doi.org/10.5465/amr.2008.31193166.

[24] Feldman DC, Bolino MC. Career Patterns of the Setf-Etnployed: Career Motivations and Career Outcomes. Journal of Small Business Management 2000;38:53-67.

[25] Sekaran U, Bougie R. Research Methods For Business: A Skill Building Approach, 7th Edition | Wiley. 7th ed. Wiley; 2016.

[26] Hair JF, Sarstedt M, Ringle CM, Mena JA. An assessment of the use of partial least squares structural equation modeling in marketing research. Journal of the Academy of Marketing Science 2012;40:414-33. https://doi.org/10.1007/s11747-011-0261-6.

[27] Kock N. Using WarpPLS in E-collaboration Studies: An Overview of Five Main Analysis Steps. IJeC 2010;6:1-11. https://doi.org/10.4018/jec.2010100101.

[28] Hair J, Hult GT, Ringle C, Sarstedt M. A Primer on Partial Least Squares Structural Equation Modeling (PLS-SEM). 2014 Faculty Bookshelf 2014.

[29] Urbach N, Ahlemann F. Structural Equation Modeling in Information Systems Research Using Partial Least Squares. Journal of Information Technology Theory and Application (JITTA) 2010;11. 